$$
\begin{aligned}
& \text { 武藤 睦 治* 坂 本 勲* } \\
& \text { 井 上 昌 弘** 岩 本利 }{ }^{* * *}
\end{aligned}
$$

\title{
Study on an Assessment of Defects for Neighbouring Embedded Cracks by
}

\author{
Yoshiharu MutoH*, Isao SAKamoto*, Masahiro Inoue** \\ and Toshikazu Iwamoto***
}

Fracture toughness tests were performed on the specimens with neighbouring embedded cracks produced by using the diffusion welding method in order to investigate the method of assessment for neighbouring embedded defects.

It was found that for $s / r_{e 2}>0.7$ (where $s / r_{e 2}$ is the ratio of the spacing of adjacent cracks and the radius of a reduced circular crack with an area equivalent to that of a larger crack), the $K$ value can be estimated by supposing isolated cracks, and for $s / r_{e 2} \leqq 0.7$, it can be estimated by using a reduced circular crack with an area equivalent to an added area of adjacent cracks. The proposed method of combining two adjacent cracks does not contradict with the one proposed in the previous paper, in which an embedded crack near surface is substituted with a surface crack. キー・ワード：内部欠陥，破壊じん性，欠陥評価，隣接欠陥

\section{1 緒言}

著者らは内部き裂に関する既設の欠陷評価規格に対 する実験的検証が行われていないこと，既設の欠陷評 価規格が過度に安全側の評価を与える傾向のあること, および破壊力学の工業的応用を進めるためにも実用上 より簡易な欠陥評価法が強く望まれることなどの情況 に鑑み，これまでに，拡散接合法を利用した内部き裂 材の製作，扣よび表面近傍に内部き裂を有する試験片 のじん性試験を行い，その久陥評価法の検討などを行 ってきた. それらによると，製作した内部き裂材の接 合部は組織的和よび材質的に母材と同等とみなすこと ができ，導入した内部き裂む十分に鋭いき裂とみなす ことができる. 表面近傍の内部き裂はりガメント比l $r_{e}$ ( $l$ はリガメント幅， $r_{e}$ は等価面積円状き裂の半径 $)$ が 0.5 より大きいとき, 引き直した等価面積円状き裂 が中央に存在するとしてK值評価できること，またり $r_{e}$ が 0.5 以下の場合, 等価面積を有する半円状表面き 裂に置き換えて $K$ 值評価できることなどが明らかとな った。

本報告では，これらの研究の一環として，表面近傍 の内部き裂と同様に実用上その取扱いが重要な隣接す る内部き裂の問題をとりあげた．隣接内部き裂を扱っ た研究としては西谷・村上打よび西岡らの数值解析の 試みがある程度であり，実験的検討の試みはこれまで
なされていないようである. 本研究では前報と同様, 払散接合法を用い隣接だ円状内部き裂材を製作し，そ のじん性試験結果から, 既設の欠陷評価規格に検討を 加光るとともに, 前報の表面近傍内部き裂の場合と類 似のき裂面積に基づいた簡便な欠陷評価手法の可能性 について検討した.

\section{2 実 験 方 法}

供試材は直径 $25.4 \mathrm{~mm}$ の低炭素鋼 S $10 \mathrm{C}$ 圧延丸棒 であり，その化学成分叔よび機械的性質をそれぞれ Table I およびIIに示す。拡散接合法を利用した内部 き裂材の製作方法等については，前報で詳細に述べた ので本報では省略するが，接合試料の片側に旋盤ある いはフライス艋を用い所定の寸法の隣接する浅い円状 あるいはだ円状切欠きを導入した後, 拡散接合するこ

Table I. Chemical composition (wt \%).

\begin{tabular}{c|c|c|c|c|c}
\hline Material & $\mathrm{C}$ & $\mathrm{Si}$ & $\mathrm{Mn}$ & $\mathrm{P}$ & $\mathrm{S}$ \\
\hline $\mathrm{S} 10 \mathrm{C}$ & 0.08 & 0.26 & 0.35 & 0.012 & 0.036 \\
\hline
\end{tabular}

Table II. Mechanical properties.

\begin{tabular}{c|c|c|c}
\hline Material & $\sigma_{y s}(\mathrm{MPa})$ & $\sigma_{B}(\mathrm{MPa})$ & R. A. (\%) \\
\hline S10C & 257.1 & 376.2 & 77.3 \\
\hline
\end{tabular}

\footnotetext{
$†$ 原稿受理 昭和60年8月15日 Received Aug. 15, 1985

* 正会員長岡技術科学大学 長岡市上富岡町, Technological University of Nagaoka, Kamitomioka-cho, Nagaoka

** 日立造船(株) 大阪市此花区桜島, Hitachi Shipbuilding and Engineering Co. Ltd., Sakurajima, Konohana-ku, Osaka

*** 三菱電機(株) 長岡京市馬場図所, Mitsubishi Electric Corporation, Banbazusho, Nagaokakyo
} 
とにより製作した。なお，拡散接合条件は前報と同じ く, 接合温度 $900^{\circ} \mathrm{C}$, 接合圧力 $9.8 \mathrm{MPa}$ 扝よび接合 時間 $30 \mathrm{~min}$ である.

製作した内部き裂試験片の最終的な形状寸法は Fig. 1 亿示寸通であり，等大あるいは非等大 $\left(b_{1}<b_{2}\right)$ の 隣接内部き裂がき裂間隔 $S$ で導入されている。じん性 試験は島津オートグラフ DSS-25T を用いクロスヘッ ド速度を $1 \mathrm{~mm} / \mathrm{min} と し$ ，また試験温度は $77 \mathrm{~K}$ (一 $196^{\circ} \mathrm{C}$ ) として行った.

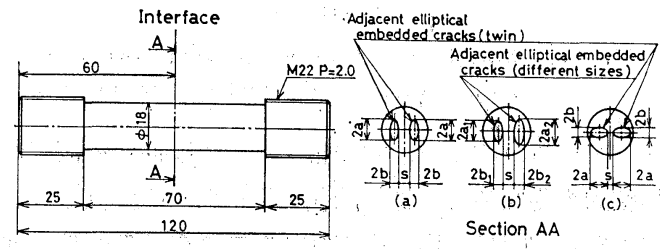

Fig. 1. Specimens.

丸棒中の隣接だ円状内部き裂の $K$ 評価式は現在不明 であるので，等大隣接だ円状内部き裂の $K$ 評価に際し ては，無限体中の等大だ円状内部き裂の近接を扱った 西谷らの数值解析結果を近似的に用いた，な招，本実 験範囲の内部き裂寸法であれば，有限体中であるため の補正は, 解析結果の存在する円状内部き裂の場合の それから類推すると最大で $6 \%$ 程度であるうと思われ る、つぎに，き裂の干渉を考慮せず単一き裂としてK 評価することが可能な範囲について検討した。 合のだ円状内部き裂の $K$ 評価に際しては，前報に従い， だ円を等価面積円に引き直し次式を用いた。

$$
\begin{aligned}
K_{\mathrm{I}}= & \frac{2 P}{\pi^{2}\left(R^{2}-r^{2}\right)} \sqrt{\pi r}\left[1+\frac{1}{2}\left(\frac{r}{R}\right)-\frac{5}{8}\left(\frac{r}{R}\right)^{2}\right. \\
& \left.+0.421\left(\frac{r}{R}\right)^{3}\right] \sqrt{1-\left(\frac{r}{R}\right)}
\end{aligned}
$$

ここで， $r$ は円状内部き裂の半径， $R$ は平滑部の半径， $P$ は負荷荷重である.

\section{3 実験結果および考察}

\section{$3 \cdot 1$ 等大隣接だ円状内部き裂}

等大隣接だ円状内部き裂材のじん性試験結果から, 西谷らの数値解析結果を用いて評価した $K_{c}$ 値とだ円 の短軸半長 $b$ で標準化したき裂間隔 $s / b$ との関係を Fig. 2 と示す. 図中の $K_{\mathrm{I} c}=22.0 \mathrm{MPa} \sqrt{\mathrm{m}}$ の実線が 本供試材の平面ひずみ破壞じん性值である。図よりわ かるように， $b / a=0.3$ 和よび1.0のいずれの場合に拉 いても西谷らの数值解析結果を用いて評価した $K_{c}$ 值 は $K_{\mathrm{I}}$ 值と良い一致を示している。な拉, 前節で述 べたようと有限体の補正（最大の場合で $6 \%$ 程度）を 加光たとしても， $K_{c}$ 值は若干小さめになるものの全 体としては $K_{\mathrm{I} c}$ 值とほぼ一致する傾向には変りがな いと思われる.

Fig. 3 に, 等大隣接だ円状内部き裂を干渉がなく単

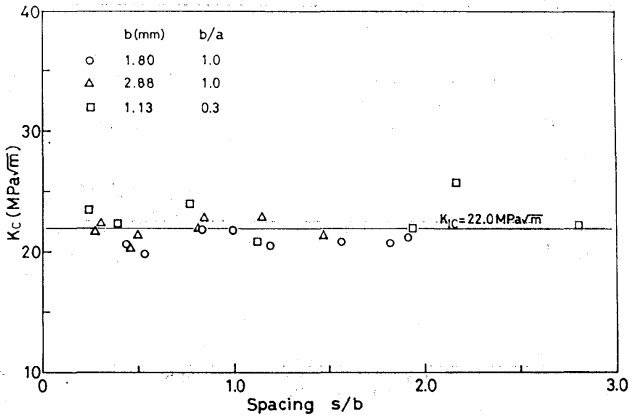

Fig. 2. Relationship between $K_{c}$-value evaluated by using the numerical results of Nishitani and Murakami and the spacing $s / b$.

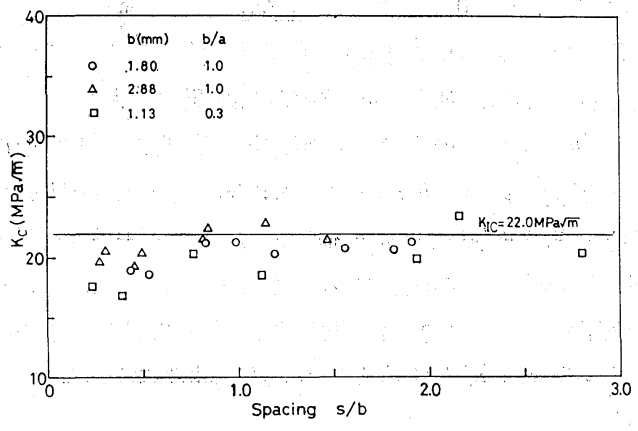

Fig. 3. Relationship between $K_{c}$-value evaluated by supposing isolated cracks and using eq. (1) and the spacing $s / b$.

独に存在するき裂とみなし，さらに等価面積円状き裂 に引き直し，式(1)を用い評価した場合の $K_{c}$ 值とき裂 間隔 $s / b$ の関係を示寸. 四からわかるよらに，b/a= 1.0 の場合 $s / b<0.6$ 飞和いて, $b / a=0.3$ の場合 $s / b$ $<1.0$ の範囲でき裂の近接による $K_{c}$ 值の減少の傾向 が認められる. 既設の各種欠陷評価規格では近接によ る欠陥の相互作用が顕著な範囲では二つの欠陥を複合 させる手法を用いているが，複合すべき近接の条件は ASME ならびに BSI では $s / b \leqq 2.0$, WES では $s / b$ $\leqq 1.0$ となっている. ASME の規格に対する理論的 根拠は明確ではないが, BSI では Kobayashi らの数 值解析結果を基に，欠陥の近接による $K$ 值の増大が単 独の場合の $20 \%$ を越えるとき，複合欠陷として扱らこ とが記述されている。また，WESでは Kobayashi ら の数值解析結果を基に $K$ 値が $20 \%$ 以上增大寸るとき複 合欠陥とすることが述べられている. BSI と WES は同様の根拠に基づいているにもかかわらず，複合条 件が異なっているが，これは各規格でさらに独自の安 全性等が考慮されているためと思わ机る．Fig. 4 は Fig. 3 の横軸を $s / r_{e}$ に置き換兄整理し直したもので ある、ここで， $r_{e}$ はだ円状内部さ裂を引き直した等価 面積を有する円状内部き裂の半径である. 図より $K_{c}$ 值は, だ円の長短軸比 $b / a$ および短軸半長 $b$ にかか 


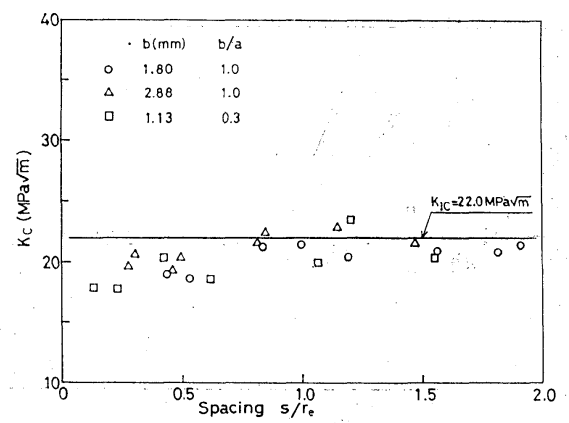

Fig. 4. Relationship between $K_{c}$-value evaluated by supposing isolated cracks and using eq. (1) and the spacing $s / r_{e}$.

わらず, $s / r_{e}>0.7$ で注涪一定値を示しており,$s / r_{e} \leqq$ 0.7 ではき裂の相互干渉により $K_{\mathrm{c}}$ 值が低下している ことがわかる. 西谷らの数值解析結果によれば $s / b=$ $0.7, b / a=1.0$ のとき, $K$ 值は単一き裂より $4 \%$ 增加 した程度であり， $b / a \neq 1.0$ の場合にも $s / r_{e}$ を用いて 整理すると $K$ 值は $b / a$ の值にかかわらず円状内部き 裂 $(b / a=1.0)$ の場合に等しくなっている. このよう な解析結果からも複合の近接条件としては $s / r_{e} \leqq 0.7$ のとき複合欠陥とするという条件で問題はないようで ある。

つぎに，隣接欠陷を単一の複合欠陷入置き換える手 法について考学る. 既設の欠陷評価規格での複合操作 は各規格とも同様で Fig. 5 亿示すごとくである. 等 大隣接だ円状内部き裂材のじん性試験結果から，Fig. 5 に示す置き換え手法により複合しただ円状き裂をさ らに等価面積円状内部き裂に引き直し, 式(1)を用い求 めた $K_{c}$ 值と $s / r_{e}$ の関係を Fig. 6 亿示す. 図よりわ かるように, $K_{c}$ 值は $b / a=0.3$ の場合 $K_{\mathrm{Ic}}$ 值に比較 的よく一致しているものの， $b, b / a$ K対する依存性 が認められ， $b$ が大きい場合には過度の安全側評価に

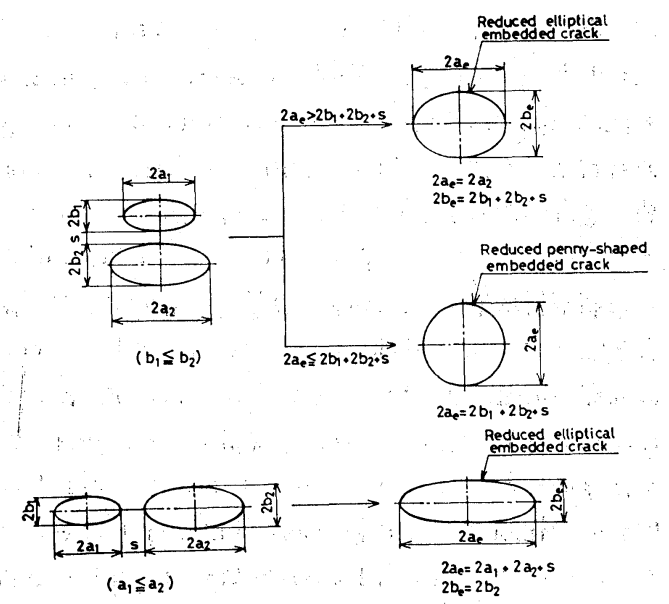

Fig. 5. Procedure for combining neighbouring cracks.

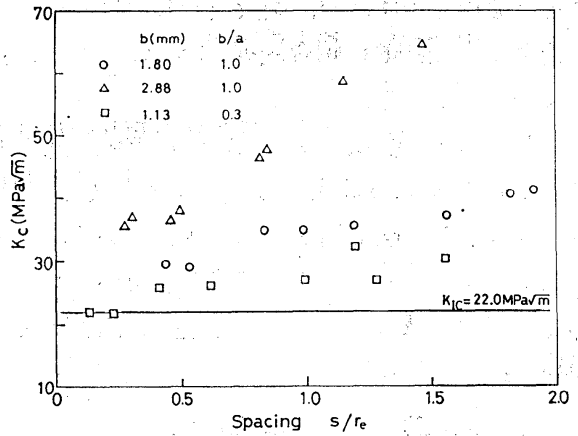

Fig. 6. Relationship between $K_{c}$-value evaluated as per the standard codes and the spacing $s / r_{e}$.

なっている，そこで，本報告では，欠陷面積の測定が 比較的容易な超音波探傷試験を用いた欠陷評価といら 立場から，隣接だ円状内部き裂を二つのき裂が持つ面 積に等しい円状内部き裂に複合してじん性評価してみ る. Fig. 7 、複合した等価面積円状内部き裂飞式(1)を 用い求めた $K_{c}$ 值と $s / r_{e}$ の関係を示す．眓よりわか るよらに， $K_{c}$ 值は $b, b / a$ の值に依存せず， 久陥評 価規格に準じた Fig. 6 の場合に比べ過度に安全側で ない比較的よい近似が得られている。

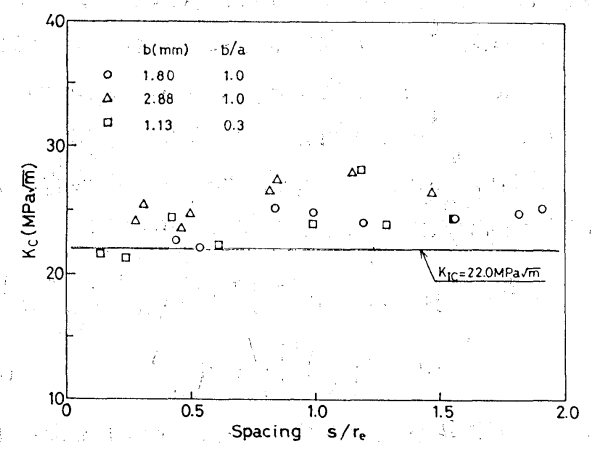

Fig. 7. Relationship between $K_{c}$-value and the spacing $s / r_{e}$ using the combined and reduced circular crack proposed in the present study.

以上の結果より，等大隣接だ円状内部き裂は $s / r_{e}>$ 0.7 の場合単一き裂として, $s / r_{e} \leqq 0.7$ の場合等価面 積円状内部き裂に複合して $K$ 值評価すれば゙よいものと 考学られる。このよらな手法は前報の表面近傍内部き 裂を表面き裂へ置き換える際の手法と同一の考兄方に 基ついて括り，統一性のあるき裂の標準化手法となっ ている.

\section{$3 \cdot 2$ 非等大隣接だ円状内部き裂}

前節に加党，さらに一般的な場合として，非等大の 隣接だ円状内部き裂についても同様の久陷評価手法が 合理的であるかについて検討する。じん性試験片に導 入した非等大隣接だ円状内部き裂の形状および位置等 性 Fig. 1 (b)に示すと拉りであり，大小関係は $b_{1}<b_{2}$ 


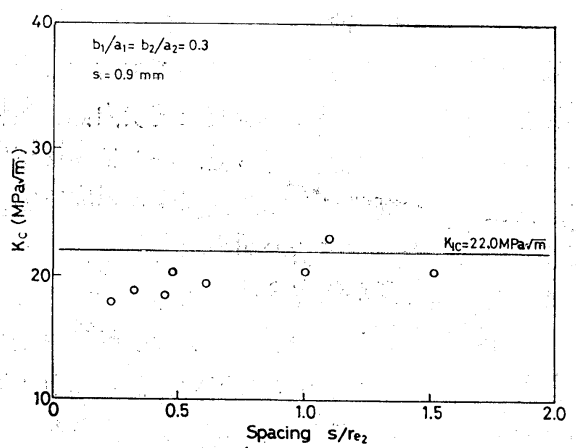

Fig. 8. Relationship between $K_{c}$-value of two unequal cracks evaluated by supposing isolated cracks and the spacing $s / r_{e 2}$.

であるまた，き裂間隔 $s$ は定 $(0.9 \mathrm{~mm})$ とし三 つのき裂の寸法比 $\left(b_{1} / b_{2}\right)$ を種々に変化させている.

Fig. 8 は, 非等大隣接だ円状内部さ裂材の破壞じん性 試験結果を大きい方のき裂だけが存在するとみなし, さらにそれを等価面積円状内部き裂に引き直し，式(1) を用いて求めた $K_{c}$ 值とき裂間隔 $s / r_{e 2}$ の関係を示し たものである。ここで， $r_{e 2}$ は大きい方のだ円状き裂 を等価面積となるよう引き直した円状内部き裂の半径 である.図より，等大隣接き裂の場合と同様， $s / r_{e 2} \leqq$ 0.7 でさ裂の近接による $K_{c}$ 值の減少の傾向が認めら 机る、度扣，等大隣接き裂の場合とは異なり，複合す べき近接の条件を与える際に，き裂間隔 $s$ をきい方 の等価面積円状き裂半径と小さい方のそれのいずれで 標準化すべきか問題となるが，非破壊検査と組合せた 欠陷評価という観点から, 検出率および測定精度が高 い大きい方のき裂半径 $r_{e 2}$ で標準化する方が合理的と 考学らる.

Fig. 9 に非等大隣接だ円状内部き裂材のじん性試験 結果から, Fig. 5 に示す既設の久陷評価規格に準じ複 合操作を行い，複合だ円状内部さ裂をさらに等価面積 円状内部き裂に引き直し, 式(1)を用い求めた $K_{c}$ 值と き裂間隔 $s / r_{e 2}$ の関係を示す. 図よりわかるように，

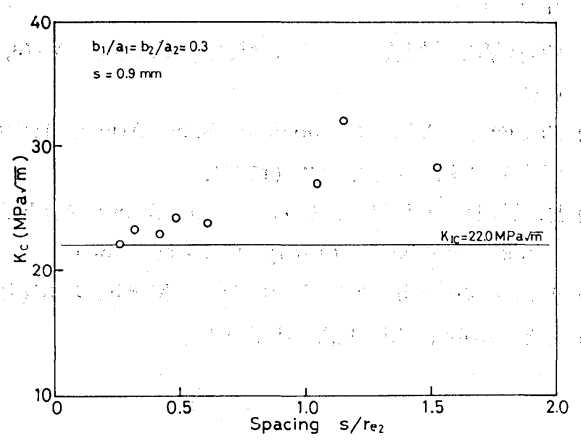

Fig. 9. Relationship between $K_{c}$-value of two unequal cracks evaluated as per the standard codes and the spacing $s / r_{e 2}$.
既設の欠陥評価規格に従った複合手法によれば， $s / r_{e 2}$ $\leqq 0.7$ の範囲で $2 \sim 20 \%$ 程度安全側の比較的よい $K_{c}$ 值評価となっている. しかし，Fig. 6 に示す等大隣接 き裂の場合から推察されるよらに，だ円状き裂の長短 軸比 $b / a$ が大きくなると過度に安全側の評価を与え るものと思われる。 Fig. 10 に, 非等大隣接だ円状内 部き裂を二つのき裂が持つ面積と等価な面積を有する 円状内部き裂に複合し, 式(1)を用いて求めた $K_{c}$ 值と $s / r_{e 2}$ の関係を示す! 図よりわかるように; 前節の等 大隣接き裂の場合と同様の等価面積円状き裂に複合す るといら本手法によれば, $s / r_{e 2} \leqq 0.7$ において $K_{c}$ 值 がほぼ $K_{\mathrm{I}}$ 值に一致するといら良好な結果を与えてい る. Fig. 11 に，き裂の干渉を考慮せず大きい方のき 裂だけ存在するとして等価面積円状き裂に引き直し，

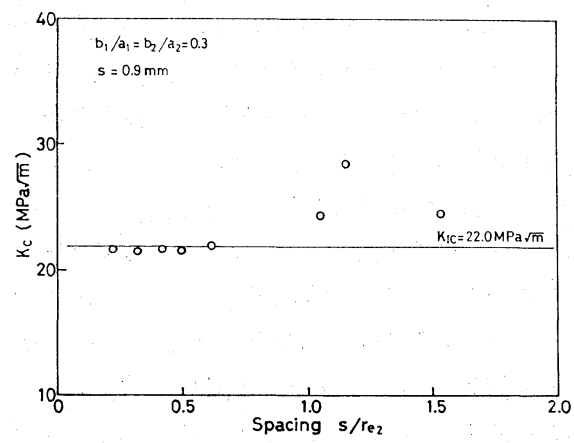

Fig. 10. Relationship between $K_{\mathrm{c}}$-value of two unequal cracks and the spacing $s / r_{e 2}$ using the combined and reduced circular crack proposed in the present study.

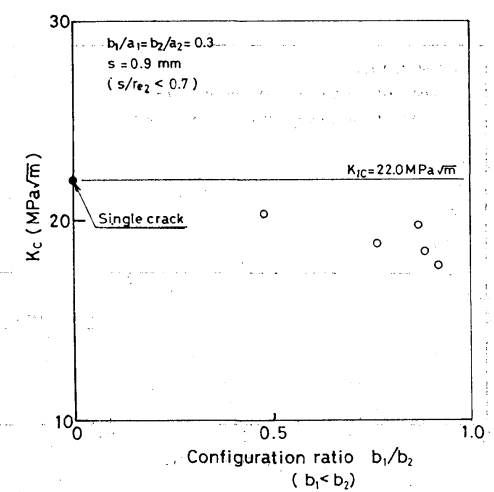

Fig. 11. Relationship between $K_{c}-$ value of two unequal cracks evaluated by supposing isolated cracks and the configuration ratio $b_{1} / b_{2}$.

式(1)を用いて求めた $K_{c}$ 值と, 非等大き裂の寸法比 $b_{1} / b_{2}$ の関係を示す: 図に扣いて $b_{1} / b_{2}=0$ の点は単一 き裂の場合， $b_{1} / b_{2}=1.0$ は等大き裂の場合に相当して いる。図からわかるように， $b_{1} / b_{2}$ の值が大きくなる 汪ど干渉効果により $K_{c}$ 值は低下して拈り，等大き裂 
の場合が干渉効果が最も大きい、したがって，前節に 示した等大き裂に関する複合条件は，本節の非等大き 裂に対しても安全側の評価を与える複合条件となって 扣り，非等大隣接き裂に対して適用しても問題ないも のと考学ら机る.

\section{$3 \cdot 3$ 長軸端同士が隣接する等大だ円状内部き裂}

実在の構造物に抹いて，隣接欠陥は前述の短軸端同 土が隣接する場合のみならず，長軸端同士が隣接する 場合もしばしば見られる。一般に前者の方が干渉効果 が大きく力学的に厳しい状態にあるが，後者の場合の 取扱いも実用上重要である。そこで，Fig. 1 (c)に示す 長軸端が隣接する等大だ円状内部き裂（ $(b / a=0.3, a$ $=2.5 \mathrm{~mm}$ ）を導入した試験片を製作し，じん性試験 を行った。

Fig. 12 に得られたじん性試験結果から，隣接さ裂 を，(1)単独き裂として（図中○印），(2)既設の欠陷評

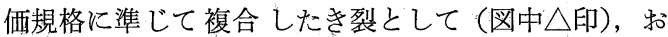
よび(3)二つのき裂がもつ面積と等しい面積を有するよ ら複合した円状き裂として (図中四印)，それぞれ引 き直した等価面積円状き裂に式(1)をを用いて評価した $K_{c}$ 值之 $s / r_{e}$ の関係を示す，図より，隣接き裂を単独 き裂とみなした場合， $s / r_{e} \leqq 0.7$ で $K_{c}$ 值が若干低下 していることがわかる。隣接さ裂を Fig. 5 に示す既 設の欠陷評価に準じて複合し評価した $K_{c}$ 值は30〜 40 \%過大な值となっている. これに対し，隣接き裂を二 つのき裂が持つ面積に等しい円状内部き裂に複合する という本手法によれば，欠陥評価規格に準じた場合ほ ど過大でなく，しかも安全側の評価が得られている。

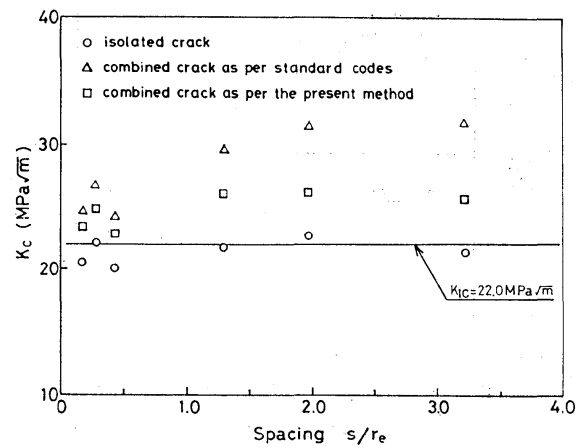

Fig. 12. Relationship between $K_{c}$-value of two equal cracks meeting with each other at the end of long axis and the spacing $s / r_{e}$.

\section{4 結言}

隣接内部き裂の欠陥評価法について検討するため, 拡散接合法を利用し，種々の隣接だ円状内部き裂材を 製作し，そのじん性試験を行った。 その結果以下のご とき，簡便でかつ既設の久陥評価法ほど過度に安全側 の評価とはならない新手法が明らかとなった.すなわ ち，隣接だ円状き裂が等大あるいは非等大であるかに かかわらずまた短軸端同士あるいは長軸端同士の隣 接にかかわらず， $s / r_{e 2}>0.7$ (等大き裂の場合 $s / r_{e}>$ 0.7) の場合，大きい方の，あるいは等大き裂の場合 には一方のき裂だけが存在するとして，そのき裂を等 価面積円状き裂に引き直し，式(1)を用い $K$ 值を評価す ればよい. また， $s / r_{e 2} \leqq 0.7$ (等大き裂の場合 $s / r_{e} \leqq$ 0.7) の場合，隣接するき裂の有する面積に等しい単 一の円状内部き裂に複合 $L$, 式(1)を用いK值評価すれ ばよい。

本手法によれば，既設の欠陥評価規格のようにき裂 形状を検出する必要がなく，き裂面積と位置を検出す ればよいので，非破壊検査，特にそれらの計測が容易 な超音波探傷試験と組合せた簡易で実用的な欠陷評価 手法となりらるものと思われる。また，分解能の制約 から，き裂間隔 $s$ が小さ隣接さ裂の場合には，き裂 の非破壊検査時にすでに自動的に複合され単一き裂と して検出されていることが考光られる．本手法はこの ような非破壊検查の実情とも合致した手法となってい る.

（昭和59年 5 月 29 日 日本材料学会第33期学術講演会にて講演）

\section{参 考 文 献}

1) ASME Boiler and Pressure Vessel Code Section XI (1980).

2) BSI PD6493 (1980).

3) WES 2805, (1980).

4) 武藤睦治, 坂本 勲, 井上昌弘, 斉藤 力, 材料, $\mathbf{3 3}$, 1153 (1984).

5) 武藤睦治, 坂本 勲, 井上昌弘, 岩本利一, 材料, 34, 1031 (1985).

6）西谷弘信，村上敬宜，日本機械学会論文集， A-40，31 (1974).

7）西岡俊久, P.E. O'Donoghue, S. N. Atluri, 日本機械 学会論文集, A-51，342 (1985).

8) H. Tada and P.C. Paris, "The Stress Analysis of Cracks Handbook" (1973) DEL Res. Corp.

9) A. S. Kobayashi, Int. J. of Fract. Mech., 1, 81(1965). 10) A.S. Kobayashi, ICM II (1976). 